\title{
Analisis Kebutuhan Pengembangan Bahan Ajar Sintaksis Arab Berbasis Android Terintegrasi Keterampilan Memecahkan Masalah
}

\author{
Chakam Failasuf*, Ihwan Rahman Bahtiar, Andri Ilham \\ Universitas Negeri Jakarta, Indonesia \\ *Coresponding Author: chakamfailasuf@unj.ac.id
}

Article History:

Received 2021-12-20

Revised 2022-01-21

Accepted 2022-02-05

DOI:

10.31949/educatio.v8i1.1822

\begin{abstract}
The development of information technology and globalization have changed the direction of current education policy. The learning process is required to combine the use of information and communication technology (ICT) with the skills of the 21st century. One form of integration is the development of Android-based teaching materials combined with problem-solving skills. The aim of this study is to conduct a needs analysis for the development of Android-based teaching materials for basic Arabic syntax (Nahwu) that are integrated into problem-solving skills. The method used in this study is a survey method. A questionnaire on the Google Form platform served as a research tool. Respondents were 40 students in the Arabic Language Education Study Program, Faculty of Language and Art at the Jakarta State University, who were randomly selected. The results indicated that students wanted the development of Android-based teaching materials for basic Arabic syntax (Nahwu) that were built into problem-solving skills. In addition, the results of the study show that it is very possible for students to access Android-based teaching materials since they are active users of Android-based devices.
\end{abstract}

Keywords: need analysis; learning materials; arabic syntax; android; problem solving

\begin{abstract}
Abstrak
Perkembangan teknologi informasi dan terjadinya globalisasi mengubah arah kebijakan pendidikan saat ini. Proses pembelajaran dituntut mengintegrasikan penggunaan Teknologi Informasi dan Komunikasi (TIK) dengan keterampilan abad ke-21. Salah satu bentuk integrasi tersebut adalah melalui pengembangan bahan ajar berbasis Android yang dipadukan dengan keterampilan memecahkan masalah. Penelitian ini bertujuan untuk melakukan analisis kebutuhan terhadap pengembangan bahan ajar Sintaksis Arab (Nabwu) Awal berbasis Android yang terintegrasi dengan keterampilan memecahkan masalah. Metode yang digunakan pada penelitian ini adalah metode survei. Instrumen penelitian yang digunakan adalah kuesioner dengan memanfaatkan platform Google Form. Responden yang terlibat adalah 40 mahasiswa Program Studi Pendidikan Bahasa Arab Fakultas Bahasa dan Seni Universitas Negeri Jakarta yang diambil secara acak. Hasil penelitian menunjukkan bahwa mahasiswa menginginkan adanya pengembangan bahan ajar Sintaksis Arab (Nahwu) Awal berbasis Android yang terintegrasi dengan keterampilan memecahkan masalah. Selain itu juga hasil penelitian menunjukkan sangat memungkinkan mahasiswa mengakses bahan ajar berbasis Android karena mereka merupakan pengguna aktif gawai berbasis Android.

Kata Kunci: analisis kebutuhan; bahan ajar; sintaksis arab; android; memecahan masalah
\end{abstract}

\section{PENDAHULUAN}

Perkembangan teknologi semakin nyata memengaruhi kehidupan manusia. Saat ini kecanggihan teknologi dan infomasi mengubah gaya hidup manusia yang semula serba manual menjadi serba digital. Perubahan gaya hidup akibat masifnya perkembangan teknologi ini dikenal dengan istilah E-life (Electronic life) (Nuryani et al., 2019). Pembelajaran sebagai salah satu aktivitas hidup manusia adalah salah satu sektor yang sangat terpengaruh dengan lahirnya E-life ini. Lahirnya pembelajaran berbasis elektronik (E-learning), 
pembelajaran berbasis komputer, maupun maupun epmbelajaran berbasis internet, merupakan bukti nyata kuatnya pengaruh teknologi terhadap pembelajaran.

Penggunaan teknologi informasi dalam pembelajaran pada akhhirnya akan mejadi sebuah keharusan dan kelaziman saat ini. Pembelajaran yang tidak terintegrasi dengan teknologi dianggap sebagai ketertinggalan. Hal itu tidak lepas dari tuntutan penguasaan keterampilan hidup di abad 21 yang mencakup penguasaan teknologi informasi dan kemampuan belajar melalui jaringan sosial digital (Griffin et al., 2012). Pernyataan tersebut selars dengan pendapat yang meyakini semakin pesatnya teknologi informasi pada akhirya akan mengubah paradigma pendidikan di abad 21 ini (Farisi, 2016).

Lahirnya budaya E-life dan tuntutan pembelajaran abad 21 di atas menjadi tantangan baru para pendidik termasuk dosen untuk menyajikan bahan pembelajaran yang terintegrasi dengan teknologi informasi. Salah satu bentuk nyata dalam penyusunan bahan ajar yang teritegrasi degan teknologi informasi sata ini adalah pembuatan bahan ajar berbasis Android. Pembuatan bahan ajar berbasis Android beberapa tahun terakhir ini memang menjadi tren di kalangan pendidik. Hal tersebut tidak lepas dari semakin meluasnya penggunaan smartphone di kalangan pelajar dan mahasiswa. BBC Indonesia melaporkan bahwa lebih dari dua pertiga siswa Indonesia (67\%) menggunakan smartphone di kelas, dan bahkan lebih banyak menggunakannya untuk mengerjakan pekerjaan rumah (81\%) (BBC News Indonesia, 2018).

Selain besarnya penggunaan smartphone di kalangan pelajar, masifya pembuatan bahan ajar berbasis Android didorong oleh keberhasilan berbagai penelitiannya sebelumnya. Pembelajaran bahasa Arab menggunakan aplikasi berbasis Android terbukti membuat peserta didik lebih fokus dan menumbuhkan gairah belajar mereka (Nuryani et al., 2019). Pembelajaran Bahasa Arab berbasis Android menghadirkan pembelajaran yang menyenangkan dan fleksibel bagi mahasiswa (Maita et al., 2018). Pembelajaran morfologi Arab (sharaf) berbasis Android memudahkan mahasiswa karena tidak terbatas ruang dan waktu (Uriawan \& Hidayat, 2017). Pembelajaran berbasis Android juga terbukti dapat meningkatkan penguasaan kaidah sintaksis Arab (Nahwu) pada mahasiswa (Sulhadi, 2020).

Meskipun penelitian pengembangan bahan ajar berbasis Android pada berbagai pembelajaran bahasa Arab dan sudah cukup banyak dilakukan, tetapi pengembangan bahan berbasis Android pada mata kuliah sintaksis Arab masih jarang dilakukan lagi, terlebih jika pengembangan bahan ajar terssebut diintegrasikan dengan keterampilan abad 21. Padahal pengembangan bahan ajar Sintaksis semacam ini sangat penting dilakukan. Hal tersebut didasarka pada dua alasan peting. Pertama, mata kuliah sintaksis Arab dianggap sebagai mata kuliah yang sangat sukar sehingga peru inovasi dalam pembelajarannya. Berdasarkan survei yang dilakukan terhadap 40 mahasiswa Program Studi pendidikan Bahasa Arab, Fakultas Bahasa dan Seni, Universitas Negeri Jakarta, diketahui $48 \%$ di antaranya menyatakan bahwa mata kuliah sintaksis Arab (Nahwu) Awal sangat sukar. Hasil survei tersebut sebegaimana tergambar pada gambar 1.

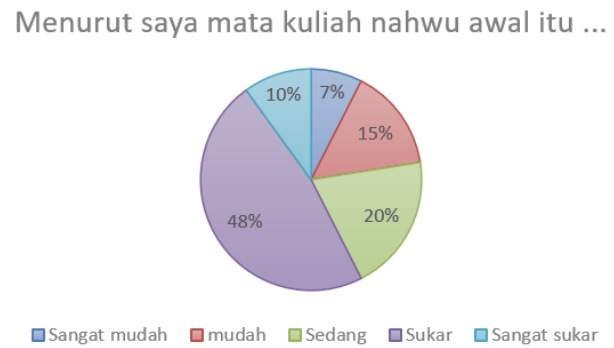

Gambar 1. Persepsi mahasiswa terhadap mata kuliah Nahwu Awal

Kedua, proses pembelajaran saat ini dituntut dilaksanakan dengan mengakomodasi berbagai keterampilan abad 21, sedangkan salah satu keterampilan abad 21 yang perlu diajarkan kepada peserta didik adalah keterampilan untuk dapat memecahkan masalah (Tan et al., 2017). Sayangnya hasil studi menunjukkan bahwa tamatan sekolah menengah, diploma dan pendidikan tinggi masih kurang kompeten dalam hal pemecahan masalah ini (Trilling \& Fadel, 2009).

Ketiga, terdapat keterkaitan erat antara Sintaksis Arab (Ilmu Nahwu) dengan keterampilan memecahkan masalah. Sintaksis Arab berbeda dengan sintaksis pada bahasa lainnya, ilmu ini dielajari untuk memecahkan 
bagaimana baris akhir suatu kata berdasarkan posisinya dalam kalimat sehinggak kalimat atau teks dapat dibaca dan dipahami (Nashoih \& Darmawan, 2019). Oleh karena itu, dapat dipahami jika penguasaan sintaksis Arab berpengaruh kuat terhadap kemampuan seseorang dalam membaca teks Arab (Mariyam, 2021).

Berdasarkan fenomena-fenomena yang telah disampaikan di atas, pengembangan bahasa ajar Sintaksis Arab berbasis Android yang terintegrasi dengan keterampilan memecahkan masalah merupakan keniscayaan saat ini. Hanya saja dalam prosesnya, penelitian pengembangan selalu diawali dengan analisis kebutuhan (need analysis) untuk menggali potensi dan masalah. Hasil analisis ini kemudian akan dijadikan dasar tahapan pengembangan selanjutya (Putri \& Billah, 2019). Oleh karena itu tujuan penelitian ini dibatasi pada analisis kebutuhan pengembangan bahan ajar Sintaksis Arab (Nahwu) Awal berbasis Android terintegrasi dengan keterampilan memecahkan masalah.

\section{METODE PENELITIAN}

Ada beberapa metode yang dapat digunakan dalam melakukan analisis kebutuhan di antaranya penilaian non-ahli, survei, wawancara terstruktur atau tidak terstruktur, penilaian praktisi ahli, audit bahasa, dan observasi partisipan (Kim, 2013). Adapun pada penelitian ini analisis kebutuhan dilakukan dengan menggunakan metode survei. Instrumen penelitian yang digunakan adalah kuesioner yang terdiri dari delapan pertanyaan dengan menggunakan skala Likert dan dibuat melalui platform Google Form. Populasi dalam penelitian ini adalah mahasiswa Program Studi Pendidikan, Fakultas Bahasa dan Seni, Universitas Negeri Jakarta. Sementara itu sampel pada penelitian ini adalah 40 orang mahasiswa yang telah mengambil mata kuliah Sintaksis Arab (Nabwu) Awal dan diambil secara acak (random).

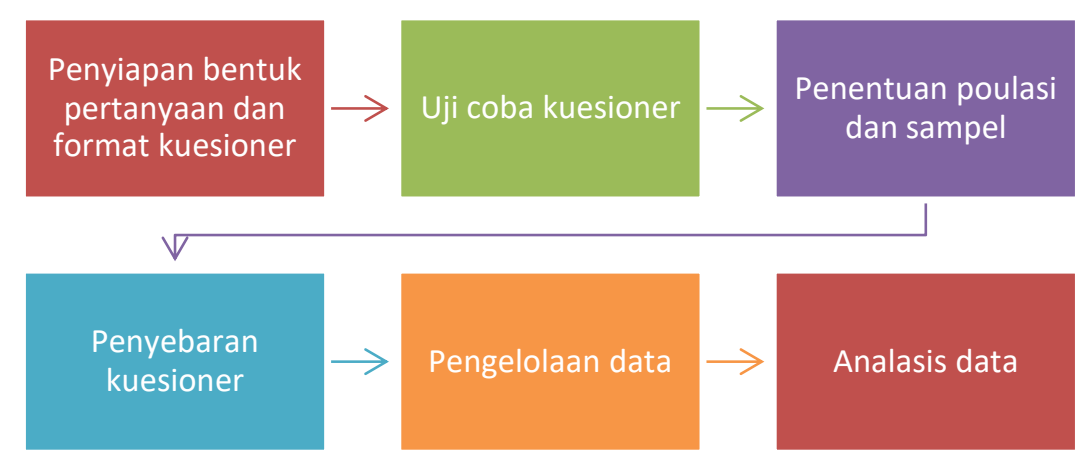

Gambar 2. Prosedur penelitian survei

Data yang dikumpulkan melalui Google Form kemudian dianalisis menggunakan interval dan konveri data kuantitatif dengan rentang $1-5$ untuk setiap pertanyaan. Skor konversi untuk setiap peranyaan dapat dilihat pada tabel 1.

Tabel 1. Konversi kuesioner ke skor

Diadaptasi dari (Kaharuddin \& Arafah, 2017)

\begin{tabular}{|c|c|c|c|c|c|}
\hline $\begin{array}{c}\text { Taraf } \\
\text { Kemungkinan }\end{array}$ & $\begin{array}{c}\text { Taraf } \\
\text { Frekuensi }\end{array}$ & $\begin{array}{c}\text { Taraf } \\
\text { Persetujuan }\end{array}$ & Taraf Petingnya & $\begin{array}{c}\text { Taraf } \\
\text { Kebermanfaatan }\end{array}$ & Skor \\
\hline Pasti & Selalu & Sangat setuju & Sangat penting & $\begin{array}{l}\text { Sangat } \\
\text { membantu }\end{array}$ & 5 \\
\hline $\begin{array}{l}\text { Besar } \\
\text { kemungkinan }\end{array}$ & Sering & Setuju & Penting & $\begin{array}{l}\text { Cukup } \\
\text { membantu }\end{array}$ & 4 \\
\hline $\begin{array}{l}\text { Sama } \\
\text { kemungkinan }\end{array}$ & Kadang-kadang & Ragu-ragu & Biasa saja & Biasa saja & 3 \\
\hline $\begin{array}{l}\text { Kecil } \\
\text { kemungkinan }\end{array}$ & Jarang & Tidak setuju & Tidak terlalu penting & $\begin{array}{l}\text { Tidak terlalu } \\
\text { membantu }\end{array}$ & 2 \\
\hline Mustahil & Tidak pernah & $\begin{array}{l}\text { Sangat tidak } \\
\text { setuju }\end{array}$ & Tidak penting & $\begin{array}{l}\text { Tidak } \\
\text { membantu sama } \\
\text { sekali }\end{array}$ & 1 \\
\hline
\end{tabular}




\section{HASIL DAN PEMBAHASAN}

Hasil angket analisis kebutuhan menunjukkan perlu adanya pengembangan bahasa ajar Sintaksi (Nahwu) Awal berbasis Android. hasil analisis jug menunjukkan bahwa mahasiswa memerlukan penguasaan keterampilan memecahkan masalah saat ini.

Tabel 2. Hasil angket analisis kebutuhan

\begin{tabular}{|c|c|c|c|c|c|c|}
\hline No. & Pertanyaan & 5 & 4 & 3 & 2 & 1 \\
\hline 1. & $\begin{array}{l}\text { Apakah Anda setuju bahwa Anda merupakan pengguna aktif gawai } \\
\text { berbasis Android? }\end{array}$ & 40 & 0 & 0 & 0 & 0 \\
\hline 2. & $\begin{array}{l}\text { Apakah Anda setuju bahwa Anda merupakan pengguna gawai berbasis } \\
\text { Android sebagai media perkuliahan dan penugasan? }\end{array}$ & 40 & 0 & 0 & 0 & 0 \\
\hline 3. & $\begin{array}{l}\text { Seberapa sering Anda menggunakan gawai berbasis Android untuk } \\
\text { kegiatan perkuliahan dan penugasan? }\end{array}$ & 16 & 24 & 0 & 0 & 0 \\
\hline 4. & $\begin{array}{l}\text { Seberapa membantu penggunaan gawai berbasis Android dalam } \\
\text { perkuliahan dan perkuliahan tugas Anda? }\end{array}$ & 22 & 14 & 4 & 0 & 0 \\
\hline 5. & $\begin{array}{l}\text { Apakah Anda setuju tidak ada kesulitan dalam menggunakan gawai } \\
\text { berbasis Android sebagai media perkuliahan dan penugasan? }\end{array}$ & 28 & 0 & 0 & 12 & 0 \\
\hline 6. & $\begin{array}{l}\text { Seberapa setujukah Anda bahwa jika bahan ajar Sintaksis Arab } \\
(\text { Nahwu }) \text { Awal disajikan dalam bentuk aplikasi berbasis Android? }\end{array}$ & 7 & 25 & 7 & 1 & 0 \\
\hline 7. & $\begin{array}{l}\text { Seberapa mungkinkan Anda dapat mengakses bahan ajar Sintaksis } \\
\text { Arab (Nahwu) Awal jika disajikan dalam bentuk aplikasi berbasis } \\
\text { Android? }\end{array}$ & 14 & 18 & 7 & 1 & 0 \\
\hline 8. & $\begin{array}{l}\text { Seberapa pentingkah penguasaan keterampilan memecahkan masalah } \\
\text { saat ini? }\end{array}$ & 22 & 14 & 4 & 0 & 0 \\
\hline
\end{tabular}

Data yang ditampilkan pada tabel 2 merupakan pertanyaan yang diajuan untuk menganalisis kebutuhan mahasiswa dan pentingnya pengembanga bahan ajar Sintaksis (Nahwu) Awal berbasis Android yang terintegrasi dengan keterampilan memecahkan masalah. Pertanyaan 1 sampai 4 diajukan untuk mengetahui kondisi mahasiswa saat ini. Pertanyaan nomor 1 dan 2 menunjukkan 40 orang mahasiswa atau 100\% 'sangat setuju’ bahwa mereka merupakan pengguna aktif gawai berbasis Android. sementara itu, pertanyaan nomor 3 terkait frekuensi penggunnaan gawai Android, hasil anget menunjukkan bahwa 24 orang mahasiswa atu 60\% menyatakan 'sering' dan 16 orang mahasiswa atau 40\% menyakan 'selalu' menggunakan gawai Android untuk kegiatan perkuliahan dan pengerjaan tugas. Sedangkan pertanyaan nomor 4 terkait kebermanfaatan gawai Andoid dalam perkuliahan dan penugasan, hasil angket menunjukkan bahwa 22 orang mahasiswa atau atau 55\% menyatakan gawai Andorid 'sangat membantu' perkuliahan dan tugas merekan, sementara itu 14 orang mahasiswa atau 35\% menyatakan 'cukup membantu'. Data yang diperolah dari jawaban pertanyaan nomor 1 sampai 4 potensi (opportunities) dalam pengembangan bahan ajar Nahwu Awal berbasis Android. Tingginya persentasi penggunaan gawai berbasis Adroid pada mahasiswa dalam kegiatan perkuliahan maupun pengerjaan tugas. Selain itu, tingginya persepsi mahasiswa tentang kebermanfaatan penggunaan gawai Android dalam aktivitas perkuliahan mereka menjadi penguat akan perlunya pengembangan bahan ajar berbasis Android ini.

Pertanyaan nomor 5 diajukan untuk mengetahui ada tidaknya kesulitan yang daialami mahasiswa dalam menggunakan gawai Android sebagai media perkuliahan maupun pengerjaan tugas. Hasil yang diperoleh dari jawaban pertanyaan nomor 5 menunjukkan bahwa 28 orang mahasiswa atau 70\% menyetakan tidak mengalami kendala, sedangkan 12 orang lainnya atau 30\% menyatakan hal yang sebaliknya. Untuk mengetahui lebih jauh terntang kesulitan yang dialami sebagian mahasiswa tersebut peneliti memberikan pertanyaan lanjutan. Berdasarkan jawaban yang diberikan, terungkap bahwa kendala yang sering mereja temui adalah aplikasi pembelajaran berbasis Android sering menghabiskan sebagian besar memori peyimpanan gawai mereka dan spesifikasi gawai yang dimiliki masih rendah. Kendala tersebut menjadi masukan untuk peneliti agar mengembangkan bahan ajar yang tidak terlalu menghabiskan memori peyimpanan dan dapat dibuka pada berbagai tipe gawai Android. 
Pertanyaan nomor 6 dan 7 diajukan untuk mengetahui kebutuhan bahan ajar berbasis Android. hasil jawaban dari pertanyaan nomor 6 menunjukkan bahwa 25 orang mahasiswa atau $63 \%$ menyatakan 'setuju' dan 7 orang mahasiswa atau 18\% menyatakan 'sangat setuju' dilakukan pengembangan bahan ajar Nahwu Awal berbasis Android. Kemudian pada hasil jawaban pertanyaan nomor 7 dapat kita ketahui bahwa 18 orang mahasiswa atau 45\% menyatakan 'besar kemungkinan', dan 14 orang mahasiswa atau 35\% menyatakan 'pasti' bisa mengakses bahan ajar Nabwu Awal jika disajikan dalam bentuk aplikasi berbasis Android. Hasil yang ditunjukkan pada jawaban pertanyaan nomor 6 dan 7 menggambarkan kekuatan (strengths) mengapa perlu dilakukan pengembangan bahan ajar berbasis Android saat ini.

Pertanyaan nomor 7 diajukan untuk mengonfirmasi kebutuhan mahasiswa terhadap penguasaan keterampilan memecahkan masalah (problem solving). Berdasarkan data yang diperoleh menujukkan bahwa mayoritas yaitu 22 orang atau 55\% menyatakan keterampilan memecahkan masalah 'sangat penting', dan 14 orang mahasiswala lainnya atau 35\% meyatakan 'penting' dikuasai saat ini. Dari data ini dapat disimpulkan bahwa mahasiswa membutuhkan keterampilan bagaimana untuk memecahkan masalah. Alasan dasar mengapa mereka membutuhkan keterampilan memecahkan masalah mayoritas menjawab karena keterampilan memecahkan masalah dibutuhkan untuk menghadapi persaingan di masa depan.

Berdasarkan data-data yang diperoleh pada tabel 2, kita dapat mengklasifikannya mejadi dua, yaitu peluang dan tantangan pengembangan bahan ajar Sintasksis Arab (Nahwu) Awal berbasis Android. Hasil jawaban pada pertanyaan nomor 1, 2, 3, 4, 6, dan 7 mengindikasikan bahwa pengembangan bahan ajar Sintaksi Arab (Nahwn) Awal berbasis Android sangat mungkin diterapkan mengingat seluruh mahasiswa merupakan pengguna aktif perangkat berbasis Android. Selain itu mayoritas mahasiswa sudah terbiasa memanfaatkan perangkat Android (smartphone) pada kegiatan pembelajaran dan penugasan mereka. Tidak mengherankan kemudian jika mayoritas mahasiswa setuju bahwa bahan ajar Sintaksis Arab (Nahwu) Awal disusun dalam bentuk bahan ajar digital berbasis Android. Bahan ajar berbasis Andorid dinilai lebih efektif dan efisien.

Saat ini mahasiswa lebih menyukai pembelajaran yang bersifat fleksibel baik waktu maupun cara aksesnya. Dengan kata lain, saat ini kita sudah memasuki era pembelajaran mobile (mobile learning). Secara sederhana mobile learning adalah kegiatan pembelajaran yang melibatkan penggunaan perangkat seluler (Crompton \& Burke, 2018). Dalam definsi lain disebutkan bahwa mobile learning merupakan proses penggunaan perangkat seluler untuk mengakses dan mempelajari materi pembelajaran untuk berkomunikasi dengan sesama siswa, pengajar, maupun institusi (El Hariry, 2015).

Mobile learning dianggap memberikan berbagai keuntungan pada mahasiswa. Ini memiliki beberapa keunggulan dan manfaat. Pertama, metode pengajaran ini dapat terjadi di mana saja, kapan saja, dan di mana saja dan proses pembelajaran tidak terbatas pada satu tempat. Mobile learning memungkinkan guru untuk mempersonalisasi instruksi kepada mahasiswanya. Selain itu, metode pengajaran ini memungkinkan siswa untuk mengatur pembelajaran sendiri (Naciri et al., 2020).

Perkembangan mobile learning sendiri semakin hari semakin meluas, terutama di era pandemi saat ini. Perkemgambar ini sebenarnya suah diprediksi oleh beberapa praktisi pembelajaran karena metode pembelajaran ini diyakini merupakan metode pembelajaran masa depan (Bahtiar, 2020). Oleh karena itu tidak mengherankan pembelajaran Sintaksis Arab yang sangat lekat dengan model pembelajaran konvensionalnya saat ini bertransformasi menuju pembelajaran seluler. Bagaimanapun perkembangan teknologi akan memengaruhi kebijakan pendidikan, oleh karena itu akan ada kebutuhan institusi pendidikan termasuk dosen di dalamnya, untuk memperkuat praktik dalam kurikulum dan penggunaan teknik dan pendekatan pengajaran yang inovatif (Toquero, 2020).

Dalam penyusunannya, bahan ajar berbasis mobile learning harus memudahkan mahasiswa sebagai pengguna. Berdasarkan kuesioner sebelumnya, diketahui bahwa kendala terbesar yang dihadapi mahasiswa saat mengakses aplikasi pembelajaran berbasis Andorid adalah kapasitas memori. Aplikasi pembelajaran yang selama ini diguakan mahasiswa memakan memori cukup besar. Kendala ini tentu saja menjadi catatan peneliti dalam mengembangkan bahan ajar. Pengembangan bahan ajar berbasis mobile learning yang dilakukan harus 
memerhatikan prinsip praktis, fleksibel, dan mungkin digunakan (Ediyani et al., 2020) serta mengakomodasi prinsip efektif, efisien, dan ekonomis (Sinaga et al., 2019).

Bahan ajar yang dikembangkan tidak saja memerhatikan hal teknis sebagaimana telah disebutkan di atas tetapi juga substansinya. Saat ini pengembangan pembelajaran mesti mengintegrasikan keterampilan abad 21 di antaranya keterampilan memecahan masalah (Problem solving). Attri (Akuba et al., 2020) mendefinisikan keterampilan memecahkan masalah sebagai kemampuan seseorang dalam menggunakan kemampuan logika yang kompleks dalam menyelesaikan masalah melalui pengumpulan fakta, analisis informasi, dan pemilihan cara yang paling efektif untuk mencapai suatu tujuan. Keterampila memecahkan masalah dianggap sebagai keterampilan yang dibutuhkan di dunia kerja saat ini (Rios et al., 2020). Wagrner (Al Kandari \& Al Qattan, 2020) bahkan menyebutkan bahwa kemampuan memecahkan masalah ini sebagai keterampilan untuk dapat bertahan (survival) di masa depan. Hal ini sejalan dengan tanggapan mahasiswa yang menyatakan bahwa memcahkan masalah adalah keterampilan masa depan yang perlu mereka kuasai. Karena keterampilan memecahkan masalah cukup krusial saat ini dan di masa depan, keterampilan ini perlu diintegrasikan dengan program pendidikan (Benander, 2018).

\section{KESIMPULAN}

Kemajuan pada bidang teknologi informasi melahirkan budaya baru pada manusia termasuk budaya belajar. Adanya perubahan budaya pembelajaran akibat perkembangan teknologi informasi ini perlu direspon oleh dosen salah satunya dengan menyusun bahan ajar berbsasis Android. Berdasarkan analisis kebutuhan yang dilakukan, pengembangan bahan ajar Sintaksis Arab (Nabwu) saat ini memungkinkan dilakukan megingat kondisi mahasiswa yang memiliki perangkat Android dan aktif menggunakannya dalam pembelajaran. Pengembangan baha ajar berbasis Android ini sendiri sebenarnya merupakan bagian dari implementasi mobile learning yang menjadi metode pembelajaran masa depan.

Dalam pengembangannya, bahan ajar Sintaksis (Nahwu) Awal ini perlu memerhatikan analisis kebutuhan mahasiswa sebagai calon penggunan. Berdasarkan analisis kebutuhan yang dilakukan, saat ini memungkinkan untuk dilakukan pengembangan bahan ajar berbasis Android karena mahasiswa Program Studi Pendidikan Bahasa Arab, FBS, UNJ merupakan penggunan aktif perangkat Android dan mayoritas mengingingkan bahan ajar Sintaksis Arab Awal disajikan dalam bentuk Android. Agar bahan ajar yang dikembangkan mengakomodasi keterampilan abad 21, pengembangannya perlu diintegrasikan dengan keterampilan memecahkan masalah.

\section{DAFTAR PUSTAKA}

Akuba, S. F., Purnamasari, D., \& Firdaus, R. (2020). Pengaruh Kemampuan Penalaran, Efikasi Diri dan Kemampuan Memecahkan Masalah Terhadap Penguasaan Konsep Matematika. JNPM (Jurnal Nasional Pendidikan Matematika), 4(1). https://doi.org/10.33603/jnpm.v4i1.2827

Al Kandari, A. M., \& Al Qattan, M. M. (2020). E-task-based learning approach to enhancing 21st-century learning outcomes. International Journal of Instruction, 13(1). https:// doi.org/10.29333/iji.2020.13136a

Bahtiar, I. R. (2020). Needs Analysis of Creating an Android-Based for Istimā‘ Learning Materials. AlMa'rifah, 17(2). https://doi.org/10.21009/almakrifah.17.02.08

BBC News Indonesia. (2018). Pelajar Indonesia jadi salah satu pengguna teknologi tertinggi di dunia - BBC News Indonesia. https://www.bbc.com/indonesia/majalah-46500293

Benander, R. (2018). Future of education and skills 2030: Conceptual learning framework. 8th Informal Working Group (IWG) Meeting, 45.

Ediyani, M., Hayati, U., Salwa, S., Samsul, S., Nursiah, N., \& Fauzi, M. B. (2020). Study on Development of Learning Media. Budapest International Research and Critics Institute (BIRCI-Journal): Humanities and Social Sciences, 3(2). https://doi.org/10.33258/birci.v3i2.989 
El Hariry, N. A. (2015). Mobile Phones as Useful Language Learning Tools. European Scientific Journal, 11(16), 298-317.

Farisi, M. I. (2016). Developing the 21st-century social studies skills through technology integration. Turkish Online Journal of Distance Education, 17(1). https://doi.org/10.17718/tojde.47374

Griffin, P., McGaw, B., \& Care, E. (2012). Assessment and teaching of 21 st century skills. In Assessment and teaching of 21st century skills. https://doi.org/10.1007/978-94-007-2324-5

Kaharuddin, A., \& Arafah, B. (2017). Using Needs Analysis To Develop English Teaching Materials in Initial Speaking Skills for Indonesian College Students Of English. The Turkish Online Journal of Design, Art and Communication TOJDAC.

Kim, H. H. (2013). Needs Analysis for English for Specific Purpose course Development for Engineering Students in Korea. International Journal of Multimedia and Ubiquitous Engineering, 8(6), 279-288. https://doi.org/10.14257/ijmue.2013.8.6.28

Maita, I., Zarnelly, Z., \& Adawiyah, A. (2018). Pembelajaran Interatif Bahasa Arab Berbasis Android. Jurnal Ilmiah Rekayasa dan Manajemen Sistem Informasi, 4(2), 123. https://doi.org/10.24014/rmsi.v4i2.6227

Mariyam, S. (2021). Hubungan Penguasaan Nahwu Sharaf dengan Kemampuan Membaca Kitab Kuning Pesantren Riyadhul Huda. Tatsqifiy: Jurnal Pendidikan Bahasa Arab, 2(1), 71. https://doi.org/10.30997/tjpba.v2i1.2828

Naciri, A., Baba, M. A., Achbani, A., \& Kharbach, A. (2020). Mobile Learning in Higher Education: Unavoidable Alternative during COVID-19. Aquademia, 4(1), ep20016. https://doi.org/10.29333/aquademia/8227

Nashoih, A. K., \& Darmawan, M. F. (2019). Pengembangan Bahan Ajar Nahwu Berbasis Kontrastif Untuk Mengatasi Interferensi Bahasa Indonesia Terhadap Bahasa Arab. Arabiyatuna: Jurnal Bahasa Arab, 3(2), 335. https://doi.org/10.29240/jba.v3i2.1008

Nuryani, E., Darpi, \& Muhtapid, A. (2019). Perancangan Aplikasi Belajar Bahasa Arab Berbasis Android Menggunakan Android Studio. Jurnal Of Innovation And Future Technology (I F T E C H), 1(2), 117-130.

Putri, W. N., \& Billah, A. (2019). Pengembangan Media Pembelajaran Bahasa Arab berwawasan Sains berbasis Mobile Android. LISANLA: Journal of Arabic Education and Literature, 3(2), 163-179. https:/ / doi.org/10.18326/lisania.v3i2.163-179

Rios, J. A., Ling, G., Pugh, R., Becker, D., \& Bacall, A. (2020). Identifying Critical 21st-Century Skills for Workplace Success: A Content Analysis of Job Advertisements. Educational Researcher, $49(2)$. https://doi.org/10.3102/0013189X19890600

Sinaga, R. M., Trisnaningsih, T., Pujiati, P., \& Sudarmansyah, D. (2019). Development of Learning Media Based on Mobil Learning Application. Jurnal Pendidikan Progresif, 9(1), 50-58. https://doi.org/10.23960/jpp.v9.i1.201907

Sulhadi, A. (2020). Media Pembelajaran Bahasa Arab Berbasis Android Dengan Menggunakan Aplikasi Arruz untuk Penguasaan Nahwu di Jurusan Sastra Arab Uin Sunan Kalijaga Yogyakarta. El-Tsaqafah, 19(1), 37-55. https: journal.uinmataram.ac.id/index.php/eltsaqafah

Tan, J. P. L., Choo, S. S., Kang, T., \& Liem, G. A. D. (2017). Educating for twenty-first century competencies and future-ready learners: research perspectives from Singapore. In Asia Pacific Journal of Education. https://doi.org/10.1080/02188791.2017.1405475

Toquero, C. M. (2020). Challenges and Opportunities for Higher Education amid the COVID-19 Pandemic: The Philippine Context. Pedagogical Research, 5(4), em0063. https://doi.org/10.29333/pr/7947

Trilling, B., \& Fadel, C. C. N.-L. . . T. 2009. (2009). 21 st century skills: learning for life in our times (1st ed). JosseyBass.

Uriawan, W., \& Hidayat, H. (2017). Rancang Bangun Aplikasi Pembelajaran Ilmu Sharaf dalam Tata Bahasa Arab Berbasis Android. ISTEK, 10(2), 107-122. 